\title{
Mites (Arachnida, Acari) on Citrus sinensis L. Osbeck orange trees in the State of Amazonas, Northern Brazil
}

\author{
Teiamar da Encarnação BOBOT ${ }^{1}$, Elizabeth FRANKLIN ${ }^{1}$, Denise NAVIA², Thierry Ray Jehlen GASNIER ${ }^{3}$, \\ Antonio Carlos LOFEGO ${ }^{4}$, Byatryz Mortágua de OLIVEIRA ${ }^{1}$
}

\begin{abstract}
Despite the importance of citriculture in Brazil, very little is known about mite populations in citrus crops in the Northern Region. In the municipality of Manaus, 12 sprayed sweet orange orchards were surveyed every two weeks during seven months to record mite species amount, and to describe the abundance and distribution of the most important species. The size and age of the orchards varied from 3,360 to $88,080 \mathrm{~m}^{2}$ and seven to 25 years, respectively. In the fourteen sampling period, leaves, twigs and fruits were collected from 12 trees, one per orchard. In total, 3,360 leaves, 672 twigs and 1,344 fruits were sampled from 168 trees. Mites were manually extracted from the fruits, and by the washing method on leaves and twigs. We identified pests with the potential to cause economic loss. Fourteen species of phytophagous and mycophagous mites from Eriophyidae, Tarsonemidae, Tenuipalpidae, and Tetranychidae were recorded. Brevipalpus phoenicis (Geijskes 1939) and Phyllocoptruta oleivora (Ashm., 1879), the two commonest phytophagous mites in other Brazilian regions were dominant, showing that local orchards are susceptible to their infestation. Eleven predatory mites were recorded, comprising $10 \%$ of the mite population, belonging to Phytoseiidae and Ascidae. Phytoseiidae was the richest family, with ten species. The results are discussed in relation to the temporal variation aspects and habitat use of the most important species. Long-term research encompassing chemical applications followed by evaluations of the mite community are necessary for a better management of the orchards, taking into consideration the seasonal phenology of key pests.
\end{abstract}

KEYWORDS: Brevipalpus, phytophagous mites, predatory mites, Phyllocoptruta.

\section{Ácarofauna de Citrus sinensis L. Osbeck no Estado do Amazonas, Brasil}

\section{RESUMO}

Apesar da importância da citricultura no Brasil, pouco se conhece sobre as populaçóes de ácaros em plantaçóes de citros no norte do país. No município de Manaus, 12 pomares de laranja doce pulverizados foram avaliados a cada duas semanas, durante sete meses, para o registro de ácaros plantícolas e para descrever a abundância e a distribuiçáo das espécies mais importantes. O tamanho e a idade dos pomares variaram de 3.360 a $88.0080 \mathrm{~m}^{2}$ e de sete a 25 anos, respectivamente. Nos 14 períodos de coleta, folhas, galhos e frutos foram coletados de uma árvore em cada pomar. No total, 3.360 folhas, 672 galhos e 1.344 frutos foram coletados de 168 árvores. Os ácaros foram extraídos dos frutos manualmente e pelo método de lavagem nas folhas e galhos. Identificamos espécies pragas com potencial de causar danos econômicos. Registramos 14 espécies de fitófagos em quatro famílias (Eriophyidae, Tarsonemidae, Tenuipalpidae, and Tetranychidae). Brevipalpus phoenicis (Geijskes 1939) (Tenuipalpidae) e Phyllocoptruta oleivora (Ashm., 1879) (Eriophyidae), as duas espécies fitófagas mais abundantes em outras regióes, foram dominantes, mostrando que a cultura de citros local é suscetível à infestação. Registramos 11 espécies de predadores das famílias Phytoseiidae e Ascidae, compreendendo $10 \%$ da população total. Phytoseiidae foi a família mais diversa, com 10 espécies. Foram discutidos aspectos da variação temporal e utilização de hábitat das espécies mais abundantes. Estudos de longo prazo, envolvendo a aplicação de acaricidas e avaliaçóes da comunidade de ácaros, são necessários para um melhor manejo dos pomares, levando-se em consideração a fenologia das pragas-chave.

PALAVRAS-CHAVE: ácaros fitófagos, ácaros predadores, Brevipalpus, Phyllocoptruta.

\footnotetext{
1 Instituto Nacional de Pesquisas da Amazônia- INPA, Caixa Postal 478, 69060-000, Manaus, AM, Brasil.

2 EEMBRAPA Recursos Genéticos e Biotecnologia, Caixa Postal 02372, 70.770-900, Brasilia, DF, Brasil.

3 Universidade Federal do Amazonas- UFAM, Av. Rodrigo Otávio Jordão Ramos 3000. 09077-900. Manaus- AM, tgasnier@ufam.edu.br

${ }^{4}$ Departamento de Zoologia e Botânica, UNESP - Universidade Estadual Paulista, Rua Cristóvão Colombo, 2265, Jardim Nazareth, 15054-000, São José do Rio Preto, São Paulo, Brazil; FAPESP Researcher.
} 


\section{INTRODUCTION}

Citrus are the most produced fruits in the world, and Brazil is the world's largest producer of sweet oranges [Citrus sinensis L. Osbeck (Sapindales, Rutaceae)]. Brazil's production is mostly concentrated in São Paulo State, Southeast Brazil, where sweet oranges plantation is grown in approximately 584 thousand hectares. In much smaller scale, with a planted area of about 2.700 thousand ha, citrus is also an important crop for the state of Amazonas, Northern Brazil (IBGE 2009). The plantations are concentrated mainly in the municipalities of Manaus, Iranduba, Rio Preto da Eva, and Manacapuru, and the most cultivate varieties of $C$. sinensis are "Pera-Lima" and "Valência".

Approximately twelve species of phytophagous mites occur in Brazilian citrus, belonging to Tetranychidae, Tenuipalpidae, Eriophyidae, Tarsonemidae and Tydeidae (Parra et al. 2003; Cassino and Rodrigues 2004, Moraes and Flechtmann 2008). Citrus leprosies is caused by Citrus leprosis virus (CiLV), an important citrus disease in South and Central America, is transmitted by Brevipalpus Donnadieu, 1875 (Acari, Tenuipalpidae) (Childers and Derrick 2003; Rodrigues et al. 2003). The most common predatory mites' families in citrus orchards are Stigmaeidae, Cheyletidae, Cunaxidae, Bdellidae, Ascidae and Phytoseiidae, with the phytoseiids being the most abundant predatory mites in this crop (Chiavegato 1991; Moraes 1992; Reis et al. 2000). Surveys conducted on plant inhabiting mites in Amazonia are limited, including few studies on oribatid mites on different plants of the natural vegetation (Beck 1968, 1971, 1972; Franklin et al. 1998); on rubber-trees [Hevea brasiliensis (Willd. ex Adr. de Juss.) Muell-Arg.] (Euphobiaceae, Euphorbiales) (Flechtmann and Arleu 1984; Fazolin and Pereira 1989; Flechtmann 1989; Feres et al. 1998; Feres 2001); on on coconut Cocos nucifera L. and native palm trees (Arecaceae) (Navia and Flechtmann 2005). Specifically on citrus (mainly oranges), Gasparotto $e t$ al. (1998) reported a high incidence of leprosis disease in citrus orchards (mainly oranges) in six municipalities in Amazonas (Rio Preto da Eva, Iranduba, Manaus, Careiro, Borba, and Nova Olinda). Rodrigues et al. (2008) reported Brevipalpus sp. mites in thirteen host plants, not including orange trees, in the cities of Manaus and Presidente Figueiredo, and in the oil exploratory base of Urucu, Amazonas. The plants showed localized symptoms and virus-like particles of Brevipalpustransmited viruses (BTVs) in their lesions.

The intensive use of pesticides in citrus orchards is a risk to the ecological balance of the environment, and also reduces the predatory mite communities (Bittencourt and Cruz 1988). Among the fruit crops, the highest quantities of pesticides are used in the citriculture (Neves et al. 2001). The frequency of the chemical control depends of the mite population
(Gasparotto et al. 1998), and accurate identification of the species together with the observation of symptoms into the agroecosystem is fundamental to define strategies of management. Otherwise, in some orchards in the municipality of Manaus, Amazonas, pesticides are regularly used, without an adequate knowledge of the species of mites affecting the plants, and more investigation may help the management of these orchards.

The objectives of this study were evaluate the diversity and abundance of mites in citrus orchards during a seven month period in Manaus, Amazonas, and to investigate the patterns of abundance of the main pest mites species on the orchards, as a first step toward development of control programs.

\section{MATERIAL AND METHODS}

The study was carried out in a commercial plantation (Citronorte Agropecuária Ltda, Brejo do Matão Farm), about $15 \mathrm{~km}$ northwest of Manaus, BR 174 highway (2'51'12"S, 6002'13"W), and about 44-50 m.a.s.l. Twelve sweet orange orchards of different ages, corresponding to a total of about 7,200 trees, planted at a spacing of $8 \times 5 \mathrm{~m}$ (Table 1) were sampled. The orchards were typically managed with three fertilization treatments per year (September/ October, November/December and February/March). Chemicals are used to control gummosis (fungus disease), in pre-inflorescence stage, anthracnose (in flowering stage), and mites (20 days after flowering), fruit-flies, termites and ants. Chemical spray was composed of $400 \mathrm{ml}$ of abamectin (VERTIMEC $18 \mathrm{CE}$ ) into 2,000 liters of water, 5 liters of mineral oil and 0.5 liters of adhesive spread.

The soils in the region are yellow clay latosols, located at the plateaus which grades to sandy soils (hydromorphic podzols) in the valleys (Chauvel et al. 1987). The climate is Ami (tropical wet) in the Köppen classification. The annual

Table 1 - Characters of sampled orchards (tree varieties, age, number of trees and size) of $C$. sinensis in Brejo do Matão farm, Manaus, AM.

\begin{tabular}{llll}
\hline Citrus variety & Age (years) & Number of trees & Size $\left(\mathrm{m}^{2}\right)$ \\
\hline Pêra Rio & 7 & 111 & 4,040 \\
Pêra Rio & 7 & 255 & 10,200 \\
\hline Pêra Rio & 7 & 470 & 18,800 \\
\hline Pêra Rio & 7 & 268 & 10,720 \\
\hline Pêra Rio & 7 & 142 & 5,680 \\
\hline Pêra Rio & 7 & 84 & 3,360 \\
\hline Pêra Rio & 9 & 2,202 & 88,080 \\
\hline Pêra Rio & 13 & 685 & 16,440 \\
\hline Pêra Rio & 16 & 1,580 & 63,200 \\
Valência & 16 & 1,047 & 65,961 \\
\hline Pêra Rio & 25 & $\sim 1,200$ & 12,000 \\
Pêra Rio & 25 & $\sim 1,200$ & 12,000 \\
\hline
\end{tabular}


pluviometry varies between 1,500 and $2,500 \mathrm{~mm}$. The annual seasonality is represented by a less raining period (June to November) and a more raining period (December to May) (Ribeiro and Adis 1984).

Because the orchards were different in size (Table 1), in each one a stand was demarcated in a central position, to minimize the border effect. The size and form (rectangular or squared) of the stand varied according to the size of each orchard. The samples were collected from trees taken at random inside of the stand in three microhabitats (leaves, twigs and fruits). Sampling was conducted at approximately every two weeks from September 2003 to March 2004 (seven months), resulting in 14 sampling periods. The first two sampling periods (September 2003) were done before the chemical treatment to control plant pest, and the last sampling period before the next chemical procedures in the farm. Twenty leaves, four twigs of about $20 \mathrm{~cm}$ and eight fruits were sampled from one tree randomly selected inside each orchard. One quarter of each microhabitat was taken for each four cardinal directions (N, S, E, and W). Leaves and twigs were half composed by mature and half by young material, and the fruits were sampled in different phases of maturation. Sampling consisted of removing the material from the outside and within the interior of the plant canopy. In the field the leaves and twigs were placed in 75\% alcohol. Each fruit was sealed in a paper bag which was placed inside of a polyethylene bag. The bags were kept in a cooler with ice packets for transport to the laboratory, where they were stored at $13{ }^{\circ} \mathrm{C}$ until processed within two days. This procedure reduces the metabolism and better preservation of the mites.

Mites on fruits were individually removed with a brush under a stereomicroscope, and placed in 75\% alcohol and $5 \%$ glycerin. Mites from leaves and twigs, previously placed in alcohol in the field, were dislodged from all samples with running water through a set of two $66 \mathrm{~cm}$ diameter overlapping metal sieves, $2 \mathrm{~mm}$ mesh on the top and $20 \mu \mathrm{m}$ on the bottom (Miranda et al. 2007). Most of the plant material was then removed and discarded, and the material retained on the bottom sieve was then washed with $75 \%$ alcohol and transferred to labeled glass bottles with $75 \%$ alcohol and $5 \%$ glycerin, for further processing and examination under the stereomicroscope. Washing technique turned out to be effective although very time-consuming as samples contained a lot of dust and soil particles. All mites were mounted in slides for later identification in a phase contrast microscope. Eriophyidae were mounted in Berlese modified medium and mites belonging to other families in Hoyer's medium. Undescribed species were identified to morphospecies. Other feeding habit mites were placed in 75\% alcohol and 5\% glycerin for future identification at the species level. Specimens were deposited in a reference collection together with the Invertebrate Collection of Instituto Nacional de Pesquisas da Amazônia (INPA) (lot 0849 to 1610).

\section{RESULTS}

\subsection{Species composition}

Two families belonging to Mesostigmata were detected: Phytoseiidae with ten species or morphospecies [(Amblyseius aerialis (Muma 1955), Amblyseius perditus Chant and Baker, 1965, Amblyseius sp. 1, Amblyseius sp. 2, Amblyseius sp. 3, Amblyseius sp. 4, Iphiseiodes zuluagai Denmark \& Muma, Proprioseiopsis neotropicus (Ehara, 1966), Proprioseiopsis sp. 1 and Typhlodromips sp. 1)], and Ascidae with one morphospecies (Asca sp.).

Prostigmata was detected, representing four families: Eriophyidae with two species, Phyllocoptruta oleivora (Ashmead 1879), and Tegolophus brunneus Flechtmann, 1999; Tarsonemidae with six species, Daidalotarsonemus sp. 1, Daidalotarsonemus sp. 2, Daidalotarsonemus sp. 3, Tarsonemus confusus Ewing, 1939, Deleonia sp. 1, and Fungitarsonemus sp. 1; Tenuipalpidae with three species, Brevipalpus californicus (Banks, 1904), Brevipalpus obovatus Donnadieu, 1875, and Brevipalpus phoenicis (Geijskes, 1939); and Tetranychidae, with three species Oligonychus gossypii (Zacher, 1921), Panonychus citri Mc Gregor, 1916, and Tetranychus mexicanus (McGregor, 1950).

\subsection{Abundance and frequency of mites}

A total of 14,678 mites were collected. Both extraction methods caught more phytophagous and mycophagous mites (68\%); the remaining was grouped as oribatid mites (14\%), predators $(10 \%)$, and others (8\%). Most of the predatory mites and mites of other feeding habits were quantified and identified to species, but they were not the major aim of the current study (Table 2).

All phytophagous and mycophagous species were recorded on leaves, twigs and fruits, except for $O$. gossypii, that was not present on fruits, and B. californicus and T. mexicanus that were recorded only on leaves. Immature forms were detected in all substrates and for all families, with highest abundance for Tenuipalpidae (Table 3). Phyllocoptruta oleivora, T. brunneus (Eriophyidae), and B. phoenicis (Tenuipalpidae) were the most abundant species, representing nearly 34,13 , and $7 \%$ of the population of phytophagous and mycophagous mites, respectively. On leaves, these three species were also the most abundant, representing nearly 38, 19 and $7 \%$ of the population of mytophagous and micophagous mites, respectively. On twigs, representatives of Daidalotarsonemus and the species $T$. confusus and P. oleivora represented nearly 
22,20 and $11 \%$ of the population, respectively. On fruits, nearly 31,13 , and $7 \%$ of the population corresponded to $P$. oleivora, T. brunneus and B. phoenicis, respectively.

The brown citrus rust mite, T. brunneus, was described from tangerine and orange in the State of São Paulo by Flechtmann in 1999. Before this description the only eriophyid mites known to occur in citrus in Brazil were $P$. oleivora and Aceria sheldoni (Ewing). A general aspect that differentiate P. oleivora and T. brunneus is the color, being the

Table 2 - Mites abundance washed from leaves and twigs and hand sorted from fruits of $C$. sinensis in Brejo do Matão farm, Manaus, AM.

\begin{tabular}{lccc}
\hline & \multicolumn{2}{c}{ Washed } & Hand sorted \\
\hline Mites & Leaves & Twigs & Fruits \\
\hline $\begin{array}{l}\text { Phytophagous and } \\
\text { mycophagous }\end{array}$ & 6,460 & 1,759 & 1,738 \\
Predatory & 592 & 607 & 264 \\
Oribatida & 603 & 1.336 & 131 \\
Others & 201 & 197 & 780 \\
\hline Total & 7,856 & 3,899 & 2,913 \\
\hline
\end{tabular}

first one yellow and the second dark, brownish-purple. The occurrence of T. brunneus in Amazonas, a so distant state from São Paulo, his type locality in Brazil, suggest that this mite can be widely disseminated in the country.

\subsection{Temporal variation of the population through the sampling period}

Temporal variations of the two most economically important species (P. oleivora and B. phoenicis) and of the second most abundant species (T. brunneus) were analyzed. Their populations were detected throughout the study period, showing different patterns (Figure 1). The numbers of individuals of the three species were low in September 2003, before the chemical control, and remained low until November 2003. Highest levels of P. oleivora and B. phoenicis were found during December 2003 (about 65 days after the chemical application) and March 2004; during this period, highest levels of rainfall occurred. The abundance of B. phoenicis population increased in December, decreasing in February and a new increase was detected in March 2004. The mean abundance of $P$. oleivora and T. brunneus populations increased approximately 50 times in February (Figure 1) in relation to September, October, November, and December.

Table 3 - Abundance, dominance (\%), and distribution of the phytophagous and mycophagous species in relation to the microhabitat on C. sinensis orchards during 14 sampling periods taken every two weeks from September 2003 to March 2004 in Brejo do Matão farm, Manaus, AM, Brazil.

\begin{tabular}{|c|c|c|c|c|c|c|c|c|c|}
\hline \multirow{2}{*}{ Family } & \multirow{2}{*}{ Species } & \multicolumn{2}{|c|}{ Leaves } & \multicolumn{2}{|c|}{ Twigs } & \multicolumn{2}{|c|}{ Fruits } & \multirow{2}{*}{ Total } & \multirow{2}{*}{$\%$} \\
\hline & & $\mathrm{N}$ & $\%$ & $\mathrm{~N}$ & $\%$ & $\mathrm{~N}$ & $\%$ & & \\
\hline \multirow[t]{4}{*}{ Eriophyidae } & Phyllocoptruta oleivora & 2,492 & 38.6 & 197 & 11.2 & 685 & 39.4 & 3,374 & 33.9 \\
\hline & Tegolophus brunneus & 1,250 & 19.3 & 22 & 1.3 & 33 & 1.9 & 1,305 & 13.1 \\
\hline & imatures & 58 & 0.9 & 1 & 0.1 & 6 & 0.3 & 65 & 0.7 \\
\hline & unidentified & 321 & 5.0 & 14 & 0.8 & 87 & 5.0 & 422 & 4.2 \\
\hline \multirow[t]{4}{*}{ Tarsonemidae } & Daidalotarsonemus spp. & 29 & 0.4 & 391 & 22.2 & 165 & 9.5 & 585 & 5.9 \\
\hline & Tarsonemus confusus & 100 & 1.5 & 362 & 20.6 & 86 & 4.9 & 548 & 5.5 \\
\hline & imatures & 21 & 0.3 & 175 & 9.9 & 8 & 0.5 & 204 & 2.0 \\
\hline & unidentified & 2 & 0.0 & 5 & 0.3 & 0 & 0.0 & 7 & 0.1 \\
\hline \multirow[t]{5}{*}{ Tenuipalpidae } & Brevipalpus californicus & 1 & 0.0 & 0 & 0.0 & 0 & 0.0 & 1 & $<0.1$ \\
\hline & Brevipalpus obovatus & 14 & 0.2 & 1 & 0.1 & 1 & 0.1 & 16 & 0.2 \\
\hline & Brevipalpus phoenicis & 454 & 7.0 & 151 & 8.6 & 136 & 7.8 & 741 & 7.4 \\
\hline & imatures & 1,011 & 15.7 & 318 & 18.1 & 505 & 29.1 & 1,834 & 18.4 \\
\hline & unidentified & 26 & 0.4 & 4 & 0.2 & 13 & 0.7 & 43 & 0.4 \\
\hline \multirow[t]{5}{*}{ Tetranychidae } & Oligonychus gossypii & 113 & 1.7 & 8 & 0.5 & 0 & 0.0 & 121 & 1.2 \\
\hline & Panonychus citri & 277 & 4.3 & 52 & 3.0 & 9 & 0.5 & 338 & 3.4 \\
\hline & Tetranychus mexicanus & 21 & 0.3 & 0 & 0.0 & 0 & 0.0 & 21 & 0.2 \\
\hline & imatures & 258 & 4.0 & 57 & 3.2 & 4 & 0.2 & 319 & 3.2 \\
\hline & unidentified & 12 & 0.2 & 1 & 0.1 & 0 & 0.0 & 13 & 0.1 \\
\hline Total of mites & & 6,460 & & 1,759 & & 1,738 & & 9,957 & \\
\hline
\end{tabular}




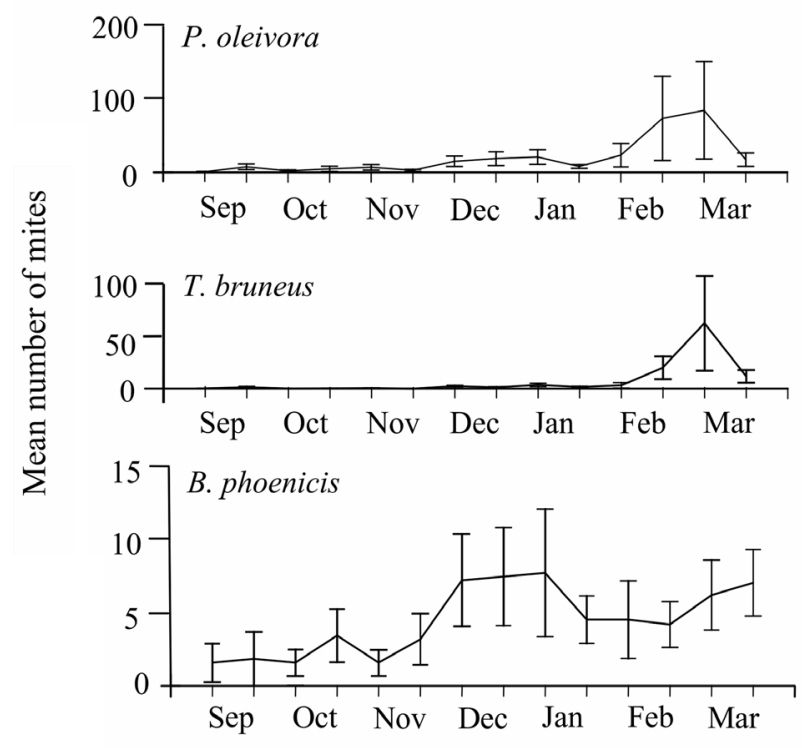

Figure 1 - Mean captures ( $\pm \mathrm{SEM}$ ) of $P$. oleivora, $T$. brunneus, and $B$. phoenicis per sampling period averaged from the total obtained from leaves, twigs and fruits over 12 trees (one per each orchard) from September 2003 until March 2004 in a sprayed C. sinensis orchard. The two periods of September occurred before the treatment to control pest in the orchards. Standard error represented by bars. See differences in scale.

\section{DISCUSSION}

\subsection{Species composition}

In general, the mite fauna in the sweet orange orchards in the Brejo do Matáo farm is similar to other registers in orange orchards in Brazil in relation to the presence of phytophagous, predatory and other mites. The fourteen species of phytophagous mites recorded in this first inventory suggest the potential for the development of pest in the orchards in Manaus. Sixteen percent of citrus consumed in Amazonas are imported from other regions, that may contribute to the introduction of pests (Coelho and Nascimento 2004), as we recorded the same major citrus pest mites that cause serious problems in other Brazilian states.

Phylocoptruta oleivora, P. citri and B. phoenicis were found throughout this study corresponding to about $44.7 \%$ of the phytophagous mites. In fact, these species are considered important phytophagous mites in Brazil (Flechtmann et al. 1974; Marconato et al. 1980; Moraes 1992; Trindade and Chiavegato 1994; Reis et al. 2000; Sato et al. 1994). Two common phytophagous mites in citrus are $B$. phoenicis and P. oleivora (Yaninek and Moraes 1991; Moraes 1992; Oliveira et al. 2007). Tegolophus brunneus, the second more abundant species in the farm, has also been reported on citrus in Brazil (Flechtmann 1999). Worldwide, Phylocoptruta oleivora and $P$. citri have major pest status, while $B$. phoenicis is considered as having major to minor pest status (Vacante 2010). These data suggest the susceptibility of the orchards to the infestation of phytophagous mites, and also to diseases, as the presence of localized symptoms of Brevipalpus-transmitted plant virus $(\mathrm{BTrV})$ was already detected for plants - not including orange trees - infested by B. phoenicis in Amazonas State (Rodrigues et al. 2008).

Tarsonemus confusus, P. citri and T. mexicanus represented only $5.5 \%, 3.4 \%$ and $0.2 \%$ of the whole mite population, respectively. Species belonging to Tarsonemus are primarily considered mycophagous (Lindquist 1986). Panonychus citri may cause leaf drop, and even though has caused pest worries in Brazil during the first years after its recording (Flechtmann and Amante 1974), nowadays it is considered a sporadic pest (Moraes and Flechtmann 2008). Tetranychus mexicanus is not considered pest in Brazil (Moraes and Flechtmann 2008), having minor pest status (Vacante 2010), but has been recorded in a large varieties of plants, especially citrus (Flechtmann and Amante 1974; Moraes and Flechtmann 1981). The period of this study (7 months) is not enough to come to the conclusion that it is unlikely that these species can represent any potential as pest in the Brejo do Matão farm.

Other species like O. gossypii, B. obovatus and $B$. californicus showed abundances lower than $1.2 \%$ of the whole phytophagous mites population. Oligonychus gossypii has been recorded as abundant in rubber trees in the Brazilian states of Acre and Amazonas (Fazolini and Pereira 1989), and its pest status is unknown (Vacante 2010). Brevipalpus californicus and $B$. obovatus were seldom detected in the farm, each one representing less than $0.1 \%$ of the total of phytophagous mites, but they also have pest status (Childers et al. 2003), and are classified as having medium to minor and major to minor pest status worldwide, respectively (Vacante 2010)

Ten species of potential natural enemies were observed in the surveys despite the low abundance. For instance, we recorded predatory mites belonging to Phytoseiidae, normally the most abundant family of predators in citrus (Yaninek and Moraes 1991). The phytoseiid mites have potential for the biological control of insects and phytophagous mites like $B$. phoenicis, P. oleivora and P. citri (Gerson et al. 2003). Iphiseiodes zuluagai, an important predator in citrus (Sato et al. 1994), was detected in the orchards in Manaus. Other authors have been recording this species in citrus orchards in Brazil (Chiavegato 1985; Bittencourt and Cruz 1988; Raga et al. 1996, Sato et al. 1994; Noronha et al. 1997; Reis et al. 2000; Parra et al. 2003; Oliveira et al. 2007). Amblyseius, considered a general predator, was the richest genus in the farm. Amblyseius aerialis has been recorded in citrus in other Brazilian states (Oliveira et al. 2007; Reis et al. 2000). Other predatory genera of mites like Proprioseiopsis, Typhlodromips (Phytoseiidae), Asca (Ascidae), and two families (Bdellidae and Cunaxidae) 
were identified. Further studies are necessary to confirm their feeding patterns and whether they are predatory or not. Therefore, these records of predatory species in the orchards show a perspective for future studies about biological control of insects and phytophagous mites in the orchards in Manaus. For example, I. zuluaga $i$ is frequently associated to B. phoenicis (Sato 1994; Raga 1996; Reis 2000), being considered one of the most efficient predators this phytophagous mites species (Albuquerque 2006).

Among phytophagous and predators, Phytoseiidae was the richest (not counting Acari belonging to the Suborder Oribatida) with 10 species. The abundance of predatory mites was low compared to the phytophagous mites in our results, what seems to be a pattern for disturbed environments or agricultural systems, as also registered by other authors (Demite and Feres 2007; Silva et al. 2008). Surveys in natural environments generally show higher equilibrium between phytophagous and predator populations of mites (Lofego and Moraes 2006; Feres et al. 2007; Castro and Moraes 2007).

\subsection{Abundance and frequency of mites}

The presence of $P$. oleivora, B. phoenicis, P. citri and T. mexicanus on the three microhabitats, agrees with Flechtmann (1989) and Childers et al. (2003), whose investigations recorded a wide variety of microhabitat that these species can inhabit on trees. Therefore, among other factors, the distribution in relation to the microhabitat can change according to the period of the year. Tarsonemid species have variable or inadequately known feeding habits. In spite of the stylettiform chelicerae, species belonging to Daidalotarsonemus prefer habitats with lichens, being frequently observed on citrus tree barks (Lindquist 1986), and probably are phytophagous (Lofego et al. 2005). This can explain the highest relative abundance (> 20\%) of species belonging to this genus on the twigs of the sweet orange orchards in Brejo do Matáo Farm.

\subsection{Temporal variation of the population through the sampling period}

We found a high variation in the abundance of P. oleivora and T. brunneus along the year. Phyllocoptruta oleivora is one of the most important pests of citrus, but little is known about its population dynamics (Bergh 2001). According to Vacante (2010), T. brunneus do not represent any danger to citros. The fact that these species presented a similar fluctuation, increasing more than 50 times in February in relation to other months, suggests that both species are strongly affected by similar factors that vary along the year.

On $C$. sinensis crops in Bahia State, the periods of highest occurrence of $P$. oleivora were variable, being affected by climatic conditions or localities (Oliveira et al. 2007). For example, in different localities, population peaks occurred either in dry or wet periods. According to Reis et al. (2000), it is difficult to explain the reasons for periods of high or lower abundances occurring in the mite population, as many variables are involved in this process, like season, long periods of drought, type of agricultural practices, orange cultivars, and influence of patches of natural vegetation near citrus crops that may serve as reservoir of natural enemies. In the Brejo do matão farm, trees were sprayed after the two first sampling periods in September 2003, which might have interfered with the levels of the different mite species. Therefore, the population of B. phoenicis and P. oleivora were already low before the chemical treatment to control plant pest in the farm (the two sampling period of September 2003), and increased 65 days after the pulverization. This is contrary to the general notion that conventional pest management practices usually have a negative impact on mite population. Quite contrary to our findings, in five years "Pêra-Rio" orange orchard in Sáo Paulo, Brazil, the effect of acaricids against $B$. phoenicis was evaluated previously and after $7,15,30,45,60,75,90$ and 120 days of the pulverization (Scapellini and Santos 2002), and all of the acaricids used (Check; Flufenoxuron +Propargite; Flufenoxuron + Dicofol; Flufenoxuron + Clorfenapyr; Hexythiazox + Propargite, Flufenoxuron and Hexythiazox) induced significant reductions to the population of B. phoenicis up to 60 days after the application. An important factor to be considered is that we are talking about differences in populations, localities and chemical management of the orchards. Production choices vary among regions and continents and influence mite control (Vacante 2010). Both results can be influenced by the initial density of B. phoenicis population, by differences in the chemical products tested, and by the variability of spray coverage. Normally, the length of residual activity of abamectin, the acaricid used in Brejo do matão farm, is short (Sousa et al. 2000), and shifts in susceptibility to this product in field populations of citrus rust mites has been reported (Bergh et al. 1999). Moreover, abamectin has been considered innocuous or slightly toxic to predatory mites (Sato et al. 1992; Raga 1996). Therefore, we elected not to make assumptions about this aspect because we have insufficient data to separate the effects of the climatic conditions from the possible effects of the chemical treatment, as June and November are the period of lowest precipitation and highest temperatures in the region of Manaus.

In summary, the citrus crops in Manaus are susceptible to the infestation of pest-mites, and have a considerable rich fauna of predatory mites and it is worthy of investigation. Further long-term research encompassing chemical applications and evaluations of the mite community are necessary as a step toward development of control programs taking in consideration the seasonal phenology of key pests for a better management of the orchards. 


\section{ACKNOWLEDGEMENTS}

To the Foundation for Research Support of the State of Amazonas (FAPEAM), throughout Project PIPT "Diversidade de Ácaros em Pomares Comerciais de Citros no Município de Manaus, AM, com Ênfase nas Famílias Tenuipalpidae (ácaro da leprose) e Eriophyidae (ácaro da ferrugem)", to Brejo do Matão farm, CITRONORTE" for financial support, and to National Council for Scientific and Technological Development (CNPq), for scholarships. The authors thanks to Dr. C. H. W. Flechtmann (ESALQ, Universidade de Sáo Paulo) for his kindness to confirm the identification of Eriophyidae mites, and also to anonymous reviewers for important recommendations and corrections.

\section{REFERENCES}

Albuquerque, F.A. 2006. Diversity of mites in organic orchard citrus and the surrounding natural vegetation, and perspectives for mass rearing of Iphiseiodes zuluagai (Acari: Phytoseiidae). PhD Thesis, Universidade Estadual Paulista, Faculdade de Ciências Agrárias e Veterinárias, Jaboticabal, SP. 95 pp. (in Portuguese, with abstract in English).

Beck, L. 1968. On the biology of some arachnids in the tropical forest of the Reserva Ducke (INPA, Manaus, Brazil). Amazoniana, 1: 247-250. (in Portuguese, with abstract in English).

Beck, L. 1971. Zoological soil classification and characterization of the Amazonian rain forest. Amazoniana, 3: 69-132. (in German, with abstract in Portuguese).

Beck, L. 1972. The influence of annual flooding on population changes of soil arthropods in the Central Amazonia rain forest region. Pedobiologia, 12: 133-148. (in German, with abstract in English).

Bergh, J.C. 2001. Ecology and aerobiology of dispersing citrus rust mites (Acari: Eriophyidae) in Central Florida. Environmental Entomology, 30: 318-326.

Bergh, J.J.; Rugg, D.; Jansson, R.K.; McCoy, C.W.; Robertson, J.L. 1999. Monitoring the susceptibility of citrus rust mite (Acari: Eriophyiidae) populations to abamectin. Journal of Economic Entomology, 92: 781-787.

Bittencourt, M.A.L.; Cruz, F.Z. 1988. Toxicity of chemical products on predatory mites (Acari: Phytoseiidae) in citrus. Anais Sociedade Entomológica do Brasil, 17: 249-261. (in Portuguese, with abstract in English).

Cassino, P.C.; Rodrigues, W.C. 2004. Fluminense citriculture: most important pests and their natural enemies. Rio de Janeiro, Seropédica. 168 pp. (in Portuguese).

Castro, T.M.M.G.; Moraes, G.J. 2007. Mite Diversity on Plants of Different Families Found in the Brazilian Atlantic Forest. Neotropical Entomology, 36: 774-782.

Chauvel, A.; Lucas, Y.; Boulet, R. 1987. On the genesis of the soil mantle of the region of Manaus, Central Amazonia, Brazil. Experientia, 43: 234-241.
Chiavegato, L.G. 1985. The mite Brevipalpus phoenicis (Geijskes, 1939) (Acari: Tenuipalpidae) responsible for citrus leprosis. Anais Simpósio de Citricultura, 2: 35-43. (in Portuguese).

Chiavegato, L.G. 1991. Mites from citrus culture, p. 601-641. In: O. Rodrigues, F. Viégas; J. Pompeu Jr.; Amaro A.A. (Eds.), Citricultura Brasileira, 2.ed., Campinas, Cargill. 941 pp. (in Portuguese).

Childers, C.C.; Derrick, K.S. 2003. Brevipalpus mites as vectors of unassigned rhabdoviruses in various crops. Experimental and Applied Acarology, 30: 1-3

Childers, C.C.; Rodrigues, J.V.C.; Welbourn, W.C. 2003. Host plants of Brevipalpus californicus, B. ovatus and B. phoenicis (Acari: Tenuipalpidae) and their potential involvement in the spread of viral diseases vectored by these mites. Experimental and Applied Acarology, 30: 29-105.

Coelho, Y.S.; Nascimento, H.G. 2004. Citriculture in Amazonas: problems, productive potentials and fruit quality. EMBRAPA: Bahia, 26 julho. (http://www.cnpmf.embrapa.br/publicacoes/ produto_em_foco/citros_26.pdf.)/ Accessed in 13/05/2009. (in Portuguese).

Demite, P.R.; Feres, R.J.F. 2007. Occurrence and fluctuation of mites populations associated with rubber tree crop of fragments of cerrado. Neotropical Entomolog, 36: 117-127. (in Portuguese, with abstract in English).

Fazolin, M.; Pereira, L.V. 1989. Occurrence of Oligonychus gossypii (Zacher 1921) (Acari: Tetranychidae) in cultivated rubber-trees. Anais da Sociedade Entomológica do Brasil, 18: 199-202. (in Portuguese, with abstract in English).

Feres, R.J.F.; Moraes, G.J. 1998. Phytoseiid mites (Acari: Phytoseiidae) from woody areas in the state of Sáo Paulo. Brazil. Systematic and Applied Acarology, 3: 125-132.

Feres, R.J.F. 2001. First record of eriophyid mites (Acari, Eriophyidac) from rubber trees in the Amazonian Forest, Brazil. Revista Brasileira de Zoologia, 18: 343-345. (in Portuguese, with abstract in English).

Feres, R.J.F; Buosi, R.; Daud, R.D.; Demite, P.R. 2007. Ecological pattern of the mites community on euphorbiaceous plants from a semi-decidual Forest remnant in the state of São Paulo. Biota Neotropica, 7, 1-10. (in Portuguese, with abstract in English).

Flechtmann, C.H.W.; Amante, E. 1974. "Citrus rust mite" Panonychus citri (Mc Gregor, 1916) citrus pest. O Biológico, 11: 195-200. (in Portuguese, with abstract in English).

Flechtmann, C.H.W. 1989. Rubber tree (Hevea sp.) a new host for Oligonychus gossypii (Zacher, 1921) (Acari: Tetranychidae). Boletim do Museu Paraense Emílio Goeldi, Serie Zoologia, 5: 27128. (in Portuguese, with abstract in English).

Flechtmann, C.H.W. 1999. Tegolophus brunneus n.sp., a new citrus rust mite from Brazil (Acari: Eriophyidae). International Journal of Acarology, 25: 265-267.

Flechtmann, C.H.W.; Arleu, R.J. 1984 Oligonychus coffeae (Nieter, 1861), a new tetranichid mite species from rubber tree (Hevea brasiliensis) in Brazil and observations about other mites on this plant. Ecossistema, 9: 123-125. (in Portuguese, with abstract in English). 
Franklin, E.; Woas, S.; Schubart, H.O.R.; Adis, J. 1998. Arboricolous oribatid mites (Acari:Oribatida) in two flooded forest in Central Amazonian. Revista Brasileira de Biologia, 58: 317-335. (in Portuguese, with abstract in English).

Gasparotto, L.; Junqueira, N.T.V.; Pereira, J.C.R. 1998. Citrus diseases in the state of Amazonas. EMBRAPA-CPAA. Manaus. Circular Técnica 6. 20 pp. (http://www.cpaa.embrapa.br/ servicos/livraria/arquivos_gratis/circ_tec6_98.pdf). Accessed in 15/05/2009. (in Portuguese).

Gerson, U.; Smiley, R.L.; Ochoa, R. 2003. Mites for Pest Control. Oxford: Blackwell Science. 539 pp.

IBGE. 2009. Brazilian Institute of Geography and Statistic. (http:// www.ibge.gov.br/estadosat/perfil.php?sigla $=a \mathrm{am})$. Accessed in 21/09/2009. (in Portuguese).

Lindquist, E.E. 1986. The world genera of Tarsonemidade (Acari: Heterostigmata): A morphological, phylogenetic and systematic revision, with a classification of family group taxa in the Hererostigmata. Memories of the Entomological Society of Canada, 136: $1-516$.

Lofego, A.C.; Ochoa, R.; Moraes, G.J. 2005. Some tarsonemid mites (Acari: Tarsonemidae) from the Brazilian "Cerrado" vegetation, with description of three new species. Zootaxa, 823: 1-27.

Lofego, A.C.; Moraes, G.J. 2006. Mites (Acari) associated to Myrtaceae in areas of cerrado in the state of São Paulo with faunistic analysis of families Tarsonemidae and Phytoseiidae. Neotropical Entomology 35:731-746. (in Portuguese, with abstract in English).

Marconato, J.R.; Tavares, S.; Brunelli Junior, H.C.; Fagan; R.; Oliveira Filho, J.C.; Carvalho, J.C.; Mariconi, F.A.M. 1980. Chemical combat to the false rust mite Phyllocoptruta oleivora (Ashm. 1879). Revista Brasileira de Ciência do Solo, 72: 53-56. (in Portuguese, with abstract in English).

Miranda, L.C.; Navia, D.; Rodrigues, J.C.V. 2007. Brevipalpus mites Donnadieu (Prostigmata: Tenuipalpidae) associated with ornamental plants in Distrito Federal, Brazil. Neotropical Entomology, 36:587-592.

Moraes, G.J. 1992. Perspectives for the use of predators in the control of phytophagous mites in Brazil. Pesquisa Agropecuária Brasileira, Brasília. 27: 236-270. (in Portuguese, with abstract in English).

Moraes, G.J; Flechtmann, C.H.W. 1981. Phytophagous mites from Northwest of Brazil. Pesquisa Agropecuária Brasileira, Brasília, 16: 177-186. (in Portuguese, with abstract in English).

Moraes, G.J.; Flechtmann, C.H.W. 2008. Manual of Acarology, basic acarology and mites of cultivated plants in Brazil. Holos, Ribeirão Preto. 288 pp. (in Portuguese).

Navia, D.; Flechtmann, C.H.W. 2005. A new genus and five new species of Eriophyoidea (Prostigmata) associated with palm trees from Brazilian Amazon. Zootaxa, 1078: 41-58.

Neves, E.M.; Dayoub, M.; Dragone, D. S.; Neves, M.F. 2001. Brazilian citrus industry: economic and financial effects,
1996-2000. Revista Brasileira de Fruticultura, 23: 432-436. (in Portuguese).

Noronha, A.C.S.; Carvalho, J.E.B.; Caldas, R.C. 1997. Mites in citrus in Tabuleiro Costeiros conditions. Revista Brasileira de Fruticultura, Cruz das Almas, 19: 373-376. (in Portuguese).

Oliveira, V.S. de; Noronha, A.C.S.; Argolo, P.S. 2007. Acarofauna in citrus orchards in the municipalities of Inhambupe and Rio Real in Bahia State. Magistra, Cruz das Almas-BA, 19: 257-261. (in Portuguese, with abstract in English).

Parra, J.R.P.; Oliveira, H.N.; Pinto, A. S. 2003. Illustrated guide for pests and beneficial insects of citrus. Piracicaba, S.P. 140 pp. (in Portuguese).

Raga, A.; Sato, M.E.; Cerávolo, L.C.; Rossi, A.C. 1996. Distribution of predatory mites (Phytoseiidae) in orange trees (Citrus sinensis L. Osbeck). Revista Ecossistema, 21: 23-25. (in Portuguese).

Reis, P.R.; Chiavegato, L.G.; Alves, E.B.; Sousa, E.O. 2000. Mites of the Phytoseiidae Family Associated with Citrus in Lavras County, Southern Minas Gerais State, Brazil. Anais da Sociedade Entomológica do Brasil, 29: 95-104. (in Portuguese, with abstract in English).

Ribeiro, M.N.G.; Adis, J. 1984. Local rainfall variability - a potencial bias for bioecological studies in the Central Amazon. Acta Amazonica, 14: 157-174.

Rodrigues, J.C.V.; Kitajima, E.W.; Childers, C.C.; Chagas, C.M. 2003. Citrus leprosis virus vectored by Brevipalpus phoenicis (Acari: Tenuipalpidae) on citrus in Brazil. Experimental and Applied Acarology, 30: 161-179.

Rodrigues, J.C.V.; Antony, L.M.K.; Salaroli, R.B.; Kitajima, E.K. 2008. Brevipalpus-associated viruses in the central Amazon Basin. Tropical Plant Pathology, 33: 112-19.

Sato, M.E.; Raga, A.; Cerávolo, L.C.; Rossi, A.C.; Rossi, A.C.; Cezário, A.C. 1992. Efect of acaricid utilization on Brevipalpus phoenicis (Geijskes, 1939) (Acari: Tenuipalpidade) and predatory mites (Family Phytoseiidae) in citrus. Revista Brasileira de Fruticultura, 14: 87-93. (in Portuguese, with abstract in English).

Sato, M.E.; Raga, A.; Cerávolo, L.C.; Rossi, A.C.; Potenza, M.R. 1994. Predatory mires in citrus orchards in Presidente Prudente, São Paulo State, Anais da Sociedade Entomológica do Brasil, 23: 435-441. (in Portuguese, with abstract in English).

Scapellini, J.R.; Santos, J.C.C. 2002 Effect of acaricides against the leprosis mite Brevipalpus phoenicis (Geijskes, 1939) on citrus orchard of Bebedouro, State of São Paulo. Arquivos do Instituto Biológico, São Paulo, 69: 39-43. (in Portuguese, with abstract in English).

Silva, F.R.; Moraes, G.J.; Knapp, M. 2008. Distribution of Tetranychus evansi and its predator Phytoseiulus longipes (Acari: Tetranychidae, Phytoseeidade) in southern Brazil. Experimental and Applied Acarology, 45: 137-145.

Sousa, J. S. I., Peixoto, A.M.P.; Toledo, F.F. 2000 (Org.). Brazilian Encyclopedia of Agriculture. EDUSP, Vol. 3. (in Portuguese). 


\section{ACTA}

Trindade, M.L.B.; Chiavegato, L.G. 1994. Biological characterization of the mites Brevipalpus obovatus D., B. californicus B. and B. phoenicis G. (Acari: Tenuipalpidae). Anais da Sociedade Entomológica do Brasil, 23: 189-195. (in Portuguese, with abstract in English).

Vacante, V. 2010. Citrus mites: identification, bionomy and control. Wallingford, Oxfordshire, UK Cambridge, MA: CABI, 378 pp.

Yaninek, J.S.; Moraes, G.J. 1991. A synopsis of classical biological control of mites in agriculture, p. 133-149. In: Dusbabek, F.,
Bukva, V. (Eds.). Modern Acarology. Prague. Academia. The Hague: SPB Academic Publishing.

Recebido em 06/08/2010

Aceito em 29/10/2010 
